\title{
Can Institutional Investor Clique Play a Governance Role? Based on the Perspective of Insider Reduction
}

\author{
Yuxiang Peng ${ }^{1, a *}$, Bingxiang $\mathrm{Li}^{2}$,b \\ ${ }^{1}$ School of Economics and Management, Xi'an University of Technology, Xi'an, China \\ ${ }^{2}$ School of Economics and Management, Xi'an University of Technology, Xi'an, China
}

\begin{abstract}
This article takes China's A-share non-financial industry listed companies from 2007 to 2015 as a sample, starting from the social network algorithm, to study whether the grouping behavior of institutional investors in the network can affect the degree of executive reduction in the future. The study found that there is a significant positive correlation between the shareholding ratio of institutional investors in group holdings and the degree of future reduction of executives. This article explores the interactive behavior of Chinese institutional investors in the network, and expands the research of institutional investors on corporate governance and executives' future reduction behaviors.
\end{abstract}

\section{Introduction}

Corporate governance, as an important mechanism for regulating various stakeholders within a company, plays a vital role in preventing management from using superior information to gain profits, thereby harming the interests of the company. Institutional investors, as one of the main bodies influencing the corporate governance mechanism, have become a force that cannot be ignored in China's capital market, especially after the China Securities Regulatory Commission put forward the strategy of "extraordinarily developing institutional investors" in 2001. However, can institutional investors truly participate in corporate governance, and use their information and professional advantages to suppress management's opportunistic behavior? There are still fierce disputes in academia. One view is that based on the consideration of their own investment safety, institutional investors have a strong incentive to participate in the governance of listed companies, supervise the information disclosure of management, and curb earnings manipulation. And by virtue of the capital scale and information advantages, the effectiveness of institutional investors' participation in corporate governance is guaranteed [1]. Another point of view emphasizes that in the context of China's high equity concentration, the relatively low proportion of individual shareholding makes it difficult for institutional investors to form a synergy in corporate governance and play a role. On the contrary, it may become a boost to stock prices Bubbles, "accomplices" to the deterioration of the company's information environment [2].
It is worth noting that the conclusions of the above studies are all based on treating institutional investors as independent and homogeneous individuals. Independent investor behavior coupled with decentralized equity will cause individual institutional investors to significantly reduce the effectiveness of corporate governance [3]. However, recent studies have found that even if a single institutional investor has a relatively low shareholding, there is the possibility of collaboration among institutional investors and the formation of highly clustered groups. The independent shareholding group under the effective cooperative group can better play the role of corporate governance, and then influence the decision-making of the holding company [4]. Crane [5] believes that the cooperation between members of institutional network groups has enhanced the overall "voicing" governance effect of institutional groups. However the same time, the joint advancement and retreat under the group binding hinders the governance effect of individual institutional investors "exit threat". In view of this, Wu et al. [6] used China's A-share listed companies as a sample and confirmed that the grouping of institutional investors in China will reduce the "exit threat" of individual investors. He also believes that as the proportion of institutional investors holding groups increases, listed companies will face a higher risk of stock price collapse. therefore, will institutional investor groupings affect insider trading, especially the reduction of senior executives?

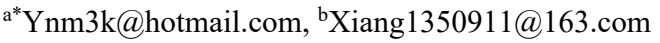




\section{Literature review and theoretical analysis}

The existing literature has studied the influencing factors of insider trading from three aspects: transaction motivation, information disclosure and governance structure [7]. As an important motivation for insider trading, grabbing excess transaction returns has been confirmed by many researchers [8]. He also believes that reverse trading through manipulation of information disclosure is the main way for insiders to obtain excess returns [9]. Relaxing the internal control and governance of insider transactions will not only promote the unearned atmosphere and weaken the efforts of management, but will eventually lead to the loss of company value [10].

As corporate insiders, corporate executives have a natural information advantage compared to external investors. This information advantage includes not only the rational judgment of the company's value, the accurate prediction of the company's future performance, but also the important information that affects the company's development but has not yet been made public [11]. Taking advantage of information, the exchange of the company's stocks before the peak and bottom of the company's earnings, and then arbitrage [12], can only be regarded as the most conventional means for insiders to earn excess returns. What's more, in order to achieve the purpose of maximizing returns, some company managements even use selective information disclosure, earnings management, "high delivery and transfer", dividend policy and other manipulation methods to increase stock prices and then reduce their holdings for profit.

So, among the institutional investors that share shares, those institutional investor groups that have smoother information flow, stronger cooperation possibilities, and tightly connected institutional investor groups will play a role in this kind of self-directed and self-performed reduction arbitrage of corporate executives What kind of effect? How does the institutional investor group affect the reduction of executives? This article believes that the impact of institutional investor grouping on the reduction of executives' holdings may be reflected in the following three aspects.

First, after the institutional investor network is connected to form a closely connected group, group members can exchange information frequently, and the communication channels between each other are smoother, and private information sharing between individuals can be realized to the greatest extent. As a result, the information collection cost of a single member is reduced, and the information advantage of institutional investors is further enhanced. And then improve the position of information disadvantage relative to the company's internal management. It helps to better participate in the governance activities of the invested company, and further strengthens the effectiveness of governance, while reducing the opacity of company information. In this case, the management's attempt to reduce holdings and arbitrage through information manipulation will be fully supervised. Company executives' reduction of holdings for the purpose of obtaining excess returns will be effectively curbed.

Secondly, the high concentration of equity in listed companies in China has caused individual institutional investors with relatively low shareholding ratios to try to use the "hand voting" governance model to directly affect the management and decision-making of the invested company. Invalidate. "Exit threat" and "voting with their feet" have become the sub-optimal choice for individual institutional investors to participate in corporate governance and form supervision. When institutional investors realize network connection, the "co-advance and retreat" formed after the group formation may lead to a decline in the governance effectiveness of the "exit threat", thereby affecting the effectiveness of the supervision of information manipulation against management. This is to a certain extent. This may lead to a decline in the transparency of company information. This leaves room and leeway for those company executives who are preparing to reduce their holdings and cash in high positions to obtain excess profits through information manipulation.

Finally, in the institutional investor network, cooperation between group members will reduce the intensity of competition between group members, thereby avoiding the loss of competitive transactions between members to the greatest extent. At the same time, however, the speed at which individual members reduce the integration of private information of institutional group members into stock prices has a negative impact on the information quality of stock prices. In addition, although institutional investors can abandon the investment target enterprise by "voting with their feet", due to considerations such as transaction restrictions, the cost and income of their own funds, etc., it is necessary to make the individual members of the group "full body". "Withdrawal", the group of institutional technical investors may drive the formation of a stock price bubble, thereby increasing the risk of the company's stock price collapse. This has given added help to the executives who are trying to obtain excess returns by reducing their holdings and provided conditions for their high-level cash out. In view of the above analysis, this article proposes a competitive hypothesis:

H1: The shareholding ratio of institutional investor Clique is significantly negatively correlated with the reduction of company executives in the future.

$\mathrm{H} 2$ : The shareholding ratio of institutional investor Clique is significantly positively correlated with the reduction of company executives in the future.

\section{Experimental design}

\subsection{Sample selection and data sources}

This article takes China's A-share non-financial industry listed companies as a sample from 2007 to 2015. The data on the shares of listed companies held by institutional investors comes from the WIND database, while executive reductions and other financial and stock price 
data are taken from the CSMAR database. According to the common practice of existing research, the observations with annual weekly returns less than 30 and missing data of related variables are eliminated, and continuous variables are processed by $1 \%$ up and down to avoid the influence of extreme outliers on the research results.

\subsection{Variable design}

A measure of institutional investor group shareholding. In order to extract various institutional investor groups from the institutional investor network, we learn from Crane[5] to establish an institutional investor network based on whether any two institutional investors jointly hold a large number of shares in any company Connect and build an institutional investor network on this basis, and then identify institutional investor groups from the network. Specifically, between any two institutional investor companies (denoted by $\mathrm{i}$ and $\mathrm{j}$ ), if they jointly hold at least any one of the same company's shares to the number of outstanding shares at the end of the $t$ quarter If it is equal to $5 \%$, a connection is established between the two of them, $X_{i j}=1$, otherwise $X_{i j}=0$, based on this, the adjacent matrix $\mathrm{A}$ of all institutional investors' pairwise links is constructed. Finally, construct an institutional investor network based on the adjacent matrix A and extract institutional investor groups. After the sports club leaves the institutional investor group, calculate the institutional investor's shareholding ratio (CliqueOwnership) according to formula (1)

$$
\begin{aligned}
& {\text { CliqueO } \text { wnership }_{i j}=}^{\sum_{j=1}^{N} \lambda_{i, j, t}\left(\text { CliqueInstitution }_{j, i}\right)}
\end{aligned}
$$

Among them, represents the proportion of company i's shares held by institution $\mathrm{j}$ in the tradable shares of company $\mathrm{i}$ in the $\mathrm{t}$ quarter, 1 represents the dummy variable that institution $\mathrm{j}$ is a member of a certain group, which belongs to 1 , and the others are 0 .

A measure of executive reduction. Taking into account the impact of capital market information leakage and investor expectations, the dividend policy will often have a substantial impact on the stock price one year before the release of the dividend policy, and executive reductions may also be carried out a year before the company's dividend announcement, so consider the impact of a lag. Therefore, this study will set whether the company has executive reduction, reduction of shares and the amount of reduction as the relevant variables for executive reduction of StkReduce ${ }_{t+1}$.

\subsection{Model construction}

In order to test the hypothesis, this article constructs formula (2) to test whether the grouping of institutional investors will increase the degree of future reduction of corporate executives:

$$
\begin{gathered}
\text { StkReduce }_{t+1}=\beta_{0}+\beta_{1} \text { Clique }_{\text {Own }} \text { St, }_{\text {R }} \\
+\beta_{2} X_{i, t}+\varepsilon_{i, t}
\end{gathered}
$$

Where is the control variable. Taking into account the impact of the company's financial characteristics and corporate governance characteristics on the reduction of institutional investor groups and senior management, the company's financial variables and equity variables are used as control variables, such as asset size, asset-liability

\begin{tabular}{|c|c|c|c|}
\hline \multirow[t]{2}{*}{ Variables } & \multicolumn{3}{|c|}{ StkReduce $_{t+1}$} \\
\hline & (1) & (2) & (3) \\
\hline CliqueOw & $\begin{array}{c}0.314^{* * *} \\
(5.61)\end{array}$ & & \\
\hline CliqueOw & & $\begin{array}{c}0.035^{* * *} \\
(2.61)\end{array}$ & \\
\hline Cos_if & & & $\begin{array}{l}0.054^{*} \\
(1.71)\end{array}$ \\
\hline Controls & Control & Control & Control \\
\hline$N$ & 7069 & 7069 & 7069 \\
\hline $\operatorname{Adj}-R^{2}$ & 0.093 & 0.091 & 0.090 \\
\hline$F$ & $13.505^{* * *}$ & $10.884^{* * *}$ & $10.718^{* * *}$ \\
\hline
\end{tabular}
ratio, cash holdings.

\section{Empirical results and analysis}

Table 1 Institutional Investor Clique and Insider Reduction

Note: the values of $\mathrm{T}$ in brackets, $*, *$, and $* *$ are significant at $10 \%, 5 \%$ and $1 \%$ levels, respectively.

From Table 1, we can see that the shareholding ratio of institutional investors in Baotuan is significantly positively correlated with the reduction of company executives in the future. And it is significant at the $1 \%$ statistical level. Hypothesis 2 has been verified.

\section{Conclusion}

This paper takes the listed companies in China's A-share non-financial industry from 2007 to 2015 as a sample, starting from the social network algorithm, and empirically researching whether the grouping behavior of institutional investors in the network can affect the degree of executive reduction in the future. The study found that the higher the shareholding ratio of institutional investors in group holdings, the higher the possibility and degree of reduction of corporate executives in the future. From the perspective of the capital market, the indicators in this article have strong practical application enlightenment for investment risk management, and deepen the understanding of institutional investor behavior.

\section{References}

1. CALLEN J L, FANG X. Religion and Stock Price Crash Risk[J]. The Journal of Financial and Quantitative Analysis, 2015, 50(1/2): 169-195. 
2. $\mathrm{Xu}$ Nianxing, $\mathrm{Yu}$ Shangyao, Yi Zhihong. Institutional investor herd behavior and stock price collapse risk[J]. Management World, 2013(07): 3143.

3. Large Shareholders and Corporate Control | Journal of Political Economy: Vol 94, No3,Part1

4. EDMANS A, HOLDERNESS C G. Blockholders: A Survey of Theory and Evidence[G] 2017, 1: 541-636.

5. CRANE A D, KOCH A, MICHENAUD $\mathrm{S}$. Institutional investor cliques and governance[J]. Journal of Financial Economics, 2019, 133(1): 175197.

6. Wu Xiaohui, Guo Xiaodong, Qiao Zheng. Institutional investors grouping and the risk of stock price collapse $[\mathrm{J}]$. China Industrial Economics, 2019(02): 117-135.

7. Wang Peng, Mao Jizhen. CEO characteristics, risk appetite and insider trading[J]. Journal of Nanjing Audit University, 2018, 15(03): 45-54.
8. Xie Deren, Cui Chenyu, Liao Ke. Listed companies' "high-end transfer" and insider stock reduction: "work after the decision" or "push the boat"? [J]. Financial Research, 2016(11): 158-173.

9. BROCKMAN P, KHURANA I K, MARTIN X. Voluntary disclosures around share repurchases[J]. Journal of Financial Economics, 2008, 89(1): 175191.

10. NOE C F. Voluntary disclosures and insider transactions[J]. Journal of Accounting and Economics, 1999, 27(3): 305-326.

11. PIOTROSKI J D, ROULSTONE D T. Do insider trades reflect both contrarian beliefs and superior knowledge about future cash flow realizations?[J]. Journal of Accounting and Economics, 2005, 39(1): $55-81$.

12. CASE K E, SHILLER R J. Is There a Bubble in the Housing Market?[J]. Brookings Papers on Economic Activity, Brookings Institution Press, 2003, 2003(2): 299-342. 